\title{
PENGUKURAN TINGKAT MANAJEMEN MUTU BERDASARKAN ISO 9001:2008 PADA PERUSAHAAN TEKNOLOGI, INFORMASI, DAN KOMUNIKASI
}

\author{
Ni Wayan Sri Ariyani ${ }^{1 *}$, Made Sudarma ${ }^{2}$, IGAM Yoga Mahaputra ${ }^{3}$ \\ ${ }^{1,2,3}$ Program Magister Teknik Elektro, Fakultas Teknik \\ Universitas Udayana \\ e-mail: sriariyani@unud.ac.id ${ }^{1}$, msudarma@unud.ac.id ${ }^{2}$, \\ yogamahaputra27@gmail.com ${ }^{3}$
}

\begin{abstract}
Abstrak
Manajemen mutu diperlukan perusahaan untuk memastikan kualitas layanan dalam rangka meningkatkan kepuasan pelanggan. Salah satu standar manajemen mutu adalah ISO 9001:2008. Audit manajemen mutu internal dengan meninjau sejauh mana klausul ISO 9001:2008 telah diterapkan pada perusahaan diperlukan untuk dapat mencegah ketidaksesuaian pada tahapan kerja dan menginisiasi perbaikannya. Penelitian ini dilakukan pada perusahaan yang bergerak dalam bidang penjualan peralatan teknologi informasi dan komunikasi, PT Baliyoni Saguna. Penelitian dilakukan dengan melihat tingkat persetujuan responden terhadap pernyataan dan pertanyaan pada klausul ISO 9001:2008 yang disampaikan melalui kuesioner dengan menggunakan skala likert. Hasil penelitian menunjukkan bahwa penerapan manajemen mutu pada klausul 4 sampai dengan 8 masing-masing adalah $50,15 \%, 49,83 \%$, $52,81 \%, 50,47 \%$, dan 49,87\%. Hasil rata-rata penerapan manajemen mutu adalah sebesar 50,62 persen. Skor tersebut menunjukkan bahwa PT. Baliyoni Saguna sudah memiliki sistem, ada bentuk, sudah diimplementasikan namun dokumentasi kurang lengkap.
\end{abstract}

Kata kunci: Audit Internal, ISO 9001:2008, Kepuasan, Penjualan, Manajemen Mutu

\begin{abstract}
Quality management is needed by companies to ensure service quality in order to increase customer satisfaction. One of the quality management standards is ISO 9001: 2008. An internal quality management audit by reviewing the extent to which the ISO 9001: 2008 clause has been applied to the company is necessary to be able to prevent non-conformities at work stages and initiate improvements. This research was conducted at a company engaged in the sale of information and communication technology equipment, PT Baliyoni Saguna. The research was conducted by looking at the level of respondent's approval of the statements and questions on the ISO 9001: 2008 clauses which were submitted through a questionnaire using a Likert scale. The results showed that the application of quality management in clauses 4 to 8 was $50.15 \%, 49.83 \%, 52.81 \%, 50.47 \%$, and $49.87 \%$, respectively. The average result of the application of quality management is 50.62 percent. This score indicates that $P T$. Baliyoni Saguna already has a system, there is a form, it has been implemented but the documentation is incomplete.
\end{abstract}

Keywords : Internal Audit, ISO 9001: 2008, Satisfaction, Sales, Quality Management

Diterima Redaksi: 18-01-2021 | Selesai Revisi: 05-03-2021 | Diterbitkan Online: 30-03-2021 DOI: https://doi.org/10.23887/janapati.v10i1.31281

\section{PENDAHULUAN}

PT Baliyoni Saguna adalah sebuah perusahaan teknologi, informasi, dan komunikasi yang bergerak di bidang penjualan. Semenjak 3 Mei 2000, Baliyoni sebagai perusahaan swasta di Bali, telah melayani kebutuhan teknologi informasi dan komunikasi puluhan instansi pemerintah dan swasta. Sebagai perusahaan yang berhubungan langsung dengan pelanggan, dibutuhkan pelayanan yang baik untuk menjamin kenyamanan.

Implementasi teknologi informasi (TI) dalam suatu organisasi berdampak pada perubahan sistem sebagai akibat perubahan 
cara kerja [1]. Salah satu upaya untuk memastikan kualitas layanan yang diberikan adalah menerapkan manajemen mutu ISO 9001:2008. Motivasi dalam menerapkan ISO 9001 dapat berasal dari internal dan eksternal [2]. Penerapan ISO diperlukan untuk meningkatkan kepuasan pelanggan dengan cara mencegah ketidak kesesuaian pada tahapan kerja termasuk perbaikan jika proses yang telah dilakukan belum mencapai hasil yang sesuai dengan sasaran mutu [3].

Perusahaan harus melakukan review manajemen secara berkala untuk melihat peningkatan kualitas manajemen dan audit internal. Audit memiliki peran penting dalam pengembangan dan peningkatan ekonomi global dan bisnis perusahaan [4]. Manajemen mutu diharapkan dapat menjadi pedoman bagi perusahaan agar perusahaan atau organisasi dapat membangun sistem manajemen mutu yang tepat, menekan biaya produksi, meningkatkan produktivitas, dan meningkatkan kepuasan pelanggan [5]. Audit teknologi tidak hanya mencakup masalah teknis tetapi melihat sumber daya lain yang menggerakkan teknologi informasi menuju tujuan organisasi [6].

ISO 9001:2008 merupakan standar ISO dalam hal manajemen mutu yang didalamnya terdapat klausul pembentuk manajemen mutu ISO 9001:2008. Klausul pendukung dalam melakukan audit manajemen mutu ISO 9001:2008 meliputi ruang lingkup, acuan normatif, istilah dan definisi, sistem manajemen mutu, tanggung jawab manajemen, manajemen sumber daya, realisasi produk, dan analisis peningkatan pengukuran [7][8][9][10][11][12][13]. ISO 9001:2008 juga menerapkan prinsip-prinsip manajemen mutu yang terdiri dari 8 prinsip seperti fokus pada pelanggan, kepemimpinan, interaksi karyawan, pendekatan proses, pendekatan sistem pada manajemen, peningkatan berkelanjutan, pendekatan faktual untuk pengambilan, dan hubungan yang saling menguntungkan dengan pemasok [14][15][16][17][18].

Pada penelitian ini, penulis melakukan analisis manajemen mutu dengan menggunakan ISO 9001:2008 pada PT Baliyoni Saguna. Penulis melakukan wawancara dan penyebaran kuesioner kepada responden yang merupakan karyawan PT Baliyoni Saguna yang memiliki SOP kerja sesuai dengan klausul yang terdapat dalam ISO 9001:2008. Responden ditentukan berdasarkan tanggung jawab manajemen dari responden sesuai dengan klausul yang ada dalam perintah audit manajemen mutu ISO 9001:2008, sedangkan klasifikasi skor kualitas manajemen mutu menggunakan skala likert [19]. Hasil penelitian ini diharapkan dapat digunakan untuk meningkatkan kualitas manajemen mutu dan layanan pelanggan pada PT Baliyoni Saguna.

\section{METODE}

\section{Pemilihan Responden}

Pada tahapan ini, penulis memilih responden yang memiliki SOP terkait klausul dalam ISO 9001:2008. Pemilihan responden dalam analisis manajemen mutu menggunakan ISO 9001:2008 di PT Baliyoni Saguna yaitu sebagai berikut.

a) Pemilihan Responden untuk Klausul 4

Klausul 4 dalam ISO 9001:2008 merupakan sistem manajemen mutu, dimana dalam klausul ini terdapat aturan yang mengharuskan suatu organisasi dibentuk, didokumentasikan, ditetapkan, dipelihara dan ditingkatkan sistem manajemen mutunya. Berdasarkan persyaratan kausal tersebut maka dipilih responden yang memiliki SOP yang sesuai yaitu manajer pemasaran dan penjualan, manajer HR/GA, dan manajer pengadaan.

b) Pemilihan Responden untuk Klausul 5

Klausul 5 dalam ISO 9001:2008 merupakan tanggung jawab manajemen, dimana klausul ini menekankan pada komitmen manajemen puncak terhadap pengembangan dan peningkatan kualitas sistem manajemen. Berdasarkan persyaratan klausul ini maka dipilih responden yang memiliki SOP yang sesuai yaitu direktur perusahaan, manajer pemasaran dan penjualan, manajer HR/GA, dan manajer keuangan.

c) Pemilihan Responden untuk Klausul 6

Klausul 6 dalam ISO 9001:2008 adalah manajemen sumber daya, dimana klausul ini menekankan pada pengelolaan sumber daya untuk meningkatkan kompetensi, kesadaran dan pelatihan manajemen yang diperlukan. Berdasarkan persyaratan klausul ini dipilih responden yang memiliki SOP sesuai yaitu: manajer pemasaran dan penjualan, manajer SDM/GA, dan manajer pengadaan.

d) Pemilihan Responden untuk Klausul 7

Klausul 7 dalam ISO 9001:2008 adalah realisasi produk, dimana klausul ini menekankan pada perencanaan realisasi produk untuk memenuhi persyaratan produk. Berdasarkan persyaratan tersebut dipilih responden yang memiliki SOP yang sesuai, yaitu: manajer pemasaran dan penjualan, manajer pengadaan, dan manajer keuangan.

e) Pemilihan Responden untuk Klausul 8

Klausul 8 dari ISO 9001:2008 adalah pengukuran, analisis dan peningkatan. Klausul 
ini menekankan pada penetapan rencana dan proses pengukuran, pemantauan, analisis dan perbaikan yang diperlukan untuk memastikan kesesuaian dan efektivitas produk sistem manajemen mutu. Berdasarkan persyaratan klausul ini dipilih responden yang memiliki SOP yang sesuai yaitu direktur perusahaan, manajer pemasaran dan penjualan, manajer HR/GA, manajer pengadaan dan manajer keuangan.

Ringkasan pemilihan responden pada masing-masing klausul tersebut ditunjukkan pada tabel 1 berikut.

Tabel 1. Pemilihan Responden

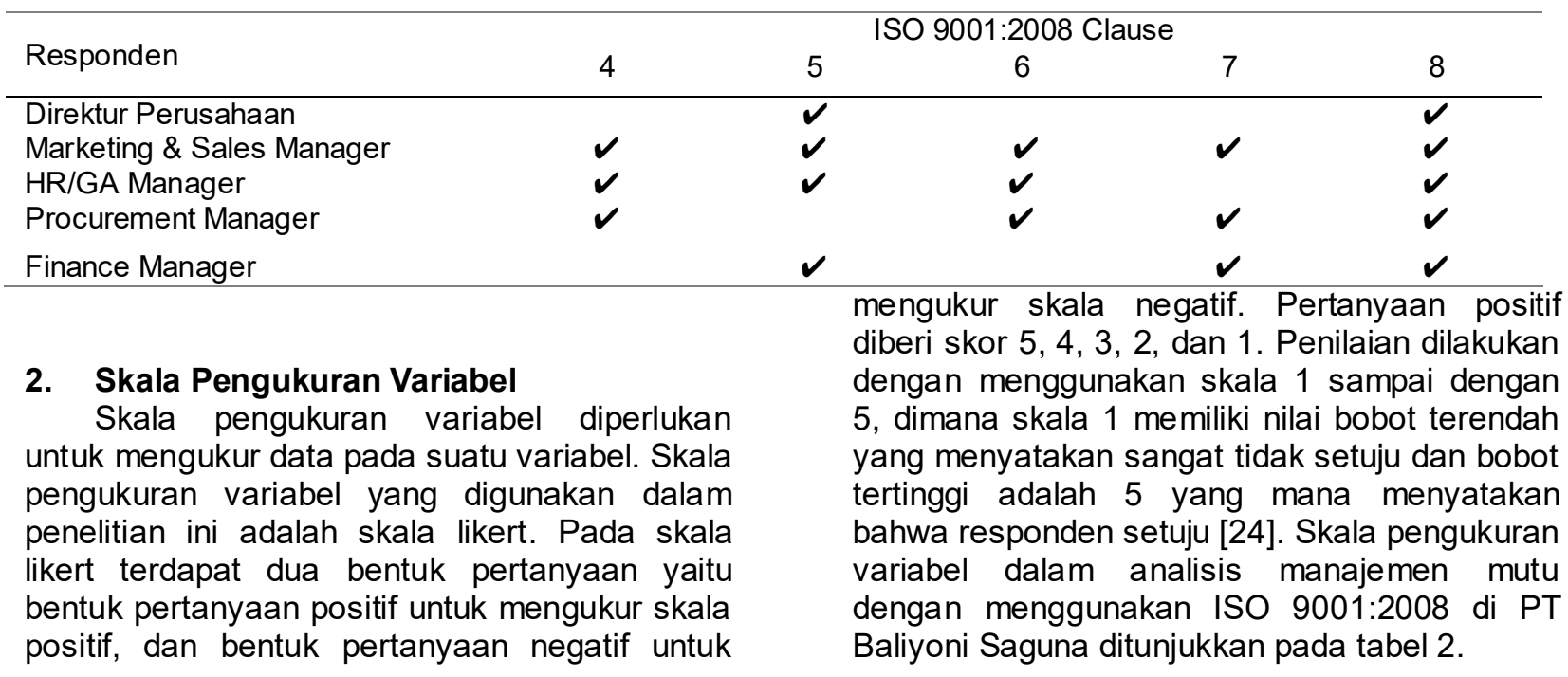

Tabel 2. Skala Likert

\begin{tabular}{clc}
\hline Nilai $(\%)$ & \multicolumn{1}{c}{ Klasifikasi } & Skor \\
\hline $81-100$ & Very Good (VG) & 5 \\
$61-80$ & Good (G) & 4 \\
$41-60$ & Average (A) & 3 \\
$21-40$ & Bad (B) & 2 \\
$<20$ & Very Bad (VB) & 1 \\
\hline
\end{tabular}

Pada tabel 2 ditunjukkan bahwa skala pengukuran yang digunakan diberi skor 1 - 5 dengan klasifikasi sangat buruk, buruk, sedang, baik, dan sangat baik. Skor skala pengukuran penerapan variabel ISO 9001:2008 dapat diklasifikasikan seperti ditunjukkan pada Tabel 3.

Tabel 3. Classified Variable

\begin{tabular}{ccc}
\hline Skor & Keterangan \\
\hline 5 & System exists, Form exists, Documentation exists, $100 \%$ applied \\
4 & System exists, Form exists, Documentation exists, implemented $<100 \%$ \\
3 & $\begin{array}{c}\text { System exists, Form exists, Documentation does not exist, applied } \\
2\end{array}$ & $\begin{array}{l}\text { System exists, Form does not exist, Documentation does not exist, applied } \\
1 \\
\text { System does not exist, Form does not exist, Documentation does not exist, }\end{array}$ \\
not implemented \\
Tabel 3 menunjukkan skor penerapan ISO & $\begin{array}{l}\text { pada perusahaan dimulai dari skor terendah } \\
\text { yaitu sistem tidak ada, formulir tidak ada, } \\
\text { dokumentasi tidak ada dan tidak diterapkan }\end{array}$ \\
yang diklasifikasikan menurut kelengkapan \\
dokumen dan manajemen mutu yang diterapkan
\end{tabular}


sampai pada skor tertinggi 5 yaitu sistem ada, formulir tersedia, dokumentasi tersedia dan $100 \%$ diterapkan.

\section{HASIL DAN PEMBAHASAN}

\section{Analisis Rekapitulasi Klausul Manajemen Mutu}

Analisis rekapitulasi manajemen mutu dilakukan untuk menghitung nilai manajemen mutu pada setiap klausul yang diujikan untuk dapat menghasilkan data yang menampilkan data yang besar mengenai persentase manajemen mutu yang diterapkan pada perusahaan sesuai klausul yang diujikan. Berikut ini adalah analisis rekapitulasi manajemen mutu pada klausul yang diujikan.

a) Rekapitulasi Klausul 4

Rekapitulasi klausul 4 dilakukan dengan menghitung skor total dan nilai skor untuk mendapatkan persentase manajemen mutu pada klausul 4 ISO 9001:2008. Hasil data kuesioner yang disebarkan kepada responden terkait penelitian klausul 4 ISO 9001-2008 yaitu sebagai

berikut.

Tabel 4. Rekapitulasi Klausul 4

\begin{tabular}{lllll}
\hline No & Question & R1 & R2 & R3 \\
\hline 1 & $4.1 . \mathrm{a}$ & 3 & 3 & 3 \\
2 & $4.1 . \mathrm{b}$ & 3 & 2 & 2 \\
3 & $4.1 . \mathrm{c}$ & 3 & 3 & 3 \\
4 & $4.1 . \mathrm{d}$ & 2 & 2 & 2 \\
5 & $4.1 . \mathrm{e}$ & 3 & 3 & 3 \\
6 & $4.1 . \mathrm{f}$ & 2 & 2 & 2 \\
7 & $4.2 .1 . \mathrm{a}$ & 2 & 3 & 2 \\
8 & $4.2 .1 . \mathrm{b}$ & 2 & 2 & 2 \\
9 & $4.2 .1 . \mathrm{c}$ & 3 & 3 & 3 \\
10 & $4.2 .1 . \mathrm{d}$ & 2 & 2 & 2 \\
11 & $4.2 .2 . \mathrm{a}$ & 3 & 3 & 3 \\
12 & $4.2 .2 . \mathrm{b}$ & 3 & 2 & 2 \\
13 & $4.2 .2 . \mathrm{c}$ & 2 & 3 & 3 \\
14 & $4.2 .3 . \mathrm{a}$ & 3 & 3 & 2 \\
15 & $4.2 .3 . \mathrm{b}$ & 3 & 2 & 2 \\
16 & $4.2 .3 . \mathrm{c}$ & 3 & 3 & 3 \\
17 & $4.2 .3 . \mathrm{d}$ & 3 & 3 & 3 \\
18 & $4.2 .3 . \mathrm{e}$ & 2 & 2 & 2 \\
19 & $4.2 .3 . \mathrm{f}$ & 3 & 3 & 2 \\
20 & $4.2 .3 . \mathrm{g}$ & 2 & 2 & \\
21 & 4.2 .4 & 2 & 2 &
\end{tabular}

\section{Total}

Dari tabel 4 dapat dilakukan perhitungan skor penerapan ISO 9001:2008 dari masingmasing responden dan rata-rata responden sebagai berikut:

$$
\begin{array}{ll}
\text { Skor Rn } & =\text { Skor Total / Nilai Total } \mathrm{x} \\
100 \% & \\
\text { Responden 1 } & =\text { Skor R1 } \\
& =54 / 105 \times 100 \% \\
& =\text { Skor R1 } \\
& =51.42 \% \\
\text { Responden 2 } & =\text { Skor R2 } \\
& =53 / 105 \times 100 \% \\
& =\text { Skor R2 }
\end{array}
$$

54

$$
\begin{aligned}
& =50.47 \% \\
\text { Responden 3 } & =\text { Skor } \mathrm{R} 3 \\
& =51 / 105 \times 100 \% \\
& =\text { Skor R3 } \\
& =48,57 \% \\
\text { Rerata klausul } 4 & =\mathrm{R} 1+\mathrm{R} 2+\mathrm{R} 3 / 3 \\
& =51,42+50,47+48,57 / 3 \\
& =50,15 \%
\end{aligned}
$$

Dari hasil perhitungan tersebut diketahui bahwa skor rata-rata penilaian responden 1 adalah 51,42 persen, responden 2 adalah 50,47 persen dan responden 3 adalah 48,57 persen sehingga dari ketiga hasil data tersebut dapat dicari skor rata-rata klausul 4 secara keseluruhan adalah 50,15 persen yang berarti 
sistem manajemen mutu pada PT. Baliyoni Saguna masuk dalam kategori sedang.

b) Rekapitulasi Klausul 5

Rekapitulasi klausul 5 dilakukan dengan menghitung skor total dan skor untuk mendapatkan persentase manajemen mutu pada klausul 5 ISO 9001:2008. Hasil data kuisioner yang disebarkan kepada responden terkait klausul 5 penelitian ISO 9001:2008 yaitu sebagai berikut.

Tabel 5. Rekapitulasi Klausul 5

\begin{tabular}{llllll}
\hline No & Question & R1 & R2 & R3 & R4 \\
\hline 1 & $5.1 . a$ & 3 & 3 & 3 & 3 \\
2 & $5.1 . b$ & 2 & 3 & 3 & 2 \\
3 & $5.1 . \mathrm{c}$ & 3 & 2 & 2 & 2 \\
4 & $5.1 . \mathrm{d}$ & 2 & 2 & 2 & 2 \\
5 & $5.1 . \mathrm{e}$ & 2 & 2 & 2 & 2 \\
6 & 5.2 & 3 & 2 & 3 & 3 \\
7 & $5.3 . \mathrm{a}$ & 2 & 2 & 2 & 3 \\
8 & $5.3 . \mathrm{b}$ & 2 & 2 & 3 & 3 \\
9 & $5.3 . \mathrm{c}$ & 3 & 3 & 3 & 3 \\
10 & $5.3 . \mathrm{d}$ & 3 & 3 & 3 & 3 \\
11 & $5.3 . \mathrm{e}$ & 2 & 2 & 3 & 3 \\
12 & 5.4 .1 & 2 & 2 & 2 & 2 \\
13 & $5.4 . \mathrm{a}$ & 2 & 2 & 2 & 2 \\
14 & $5.4 . \mathrm{b}$ & 2 & 2 & 2 & 2 \\
15 & 5.5 .1 & 3 & 3 & 3 & 3 \\
16 & $5.5 .2 . \mathrm{a}$ & 3 & 2 & 3 & 3 \\
17 & $5.5 .2 . \mathrm{b}$ & 3 & 3 & 3 & 2 \\
18 & $5.5 .2 . \mathrm{c}$ & 2 & 3 & 3 & 3 \\
19 & 5.5 .3 & 3 & 3 & 3 & 3 \\
20 & 5.6 .1 & 2 & 3 & 2 & 3 \\
21 & $5.6 .2 . \mathrm{a}$ & 2 & 2 & 2 & 2 \\
22 & $5.6 .2 . \mathrm{b}$ & 3 & 2 & 2 & 3 \\
23 & $5.6 .2 . \mathrm{c}$ & 3 & 3 & 3 & 3 \\
24 & $5.6 .2 . \mathrm{d}$ & 3 & 3 & 3 & 3 \\
25 & $5.6 .2 . \mathrm{e}$ & 2 & 2 & 2 & 2 \\
26 & $5.6 .2 . \mathrm{f}$ & 2 & 2 & 3 & 2 \\
27 & $5.6 .2 . \mathrm{g}$ & 2 & 2 & 2 & 2 \\
28 & $5.6 .3 . \mathrm{a}$ & 3 & 3 & 3 & 3 \\
29 & $5.6 .3 . \mathrm{b}$ & 2 & 2 & 2 & 2 \\
30 & $5.6 .3 . \mathrm{c}$ & 2 & 72 & 76 & 77 \\
\hline Total & & 2 & 2 & 3 \\
\hline & & 2 & 2 & 2 & 2
\end{tabular}

Dari tabel 5 dapat dilakukan perhitungan skor penerapan ISO 9001:2008 dari masingmasing responden dan rata-rata responden sebagai berikut.

$$
\begin{aligned}
\text { Skor Rn } & =\text { Skor Total / Nilai Total } \mathrm{x} \\
\begin{aligned}
100 \% \\
\text { Responden } 1
\end{aligned} & =\text { Skor R1 } \\
& =74 / 150 \times 100 \% \\
& =\text { Skor R1 } \\
& =49,33 \% \\
\text { Responden 2 } & =\text { Skor R2 } \\
& =72 / 150 \times 100 \% \\
& =\text { Skor R2 } \\
& =48 \%
\end{aligned}
$$

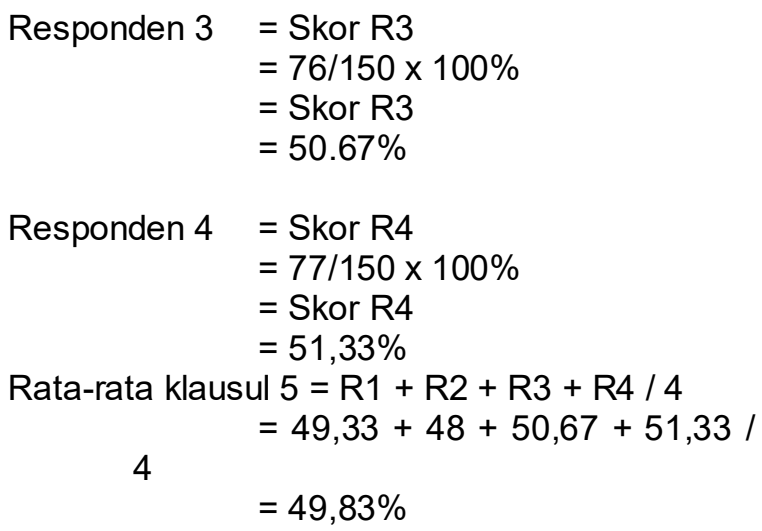


Dari hasil perhitungan tersebut didapatkan rata-rata skor penilaian responden 1 sebesar 49,33 persen, responden 2 sebesar 48 persen, responden 3 sebesar 50,67 persen dan responden 4 sebesar 51,33 persen sehingga hasil skor rata-rata keseluruhan klausul 5 adalah 49,83 persen yang berarti sistem manajemen mutu pada PT. Baliyoni Saguna masuk dalam kategori sedang. c) Rekapitulasi Klausul 6

Rekapitulasi klausul 6 dilakukan dengan menghitung skor total dan nilai skor untuk mendapatkan persentase manajemen mutu pada klausul 6 ISO 9001:2008. Hasil data kuisioner yang disebarkan kepada responden terkait klausul 5 penelitian ISO 9001:2008 yaitu sebagai

Tabel 6. Rekapitulasi Klausul 6

\begin{tabular}{ccccc}
\hline No & Question & R1 & R2 & R3 \\
\hline 1 & $6.1 . \mathrm{a}$ & 3 & 3 & 3 \\
2 & $6.1 . \mathrm{b}$ & 3 & 2 & 3 \\
3 & 6.2 .1 & 3 & 3 & 3 \\
4 & $6.2 .2 . \mathrm{a}$ & 2 & 2 & 2 \\
5 & $6.2 .2 . \mathrm{b}$ & 2 & 2 & 2 \\
6 & $6.2 .2 . \mathrm{c}$ & 3 & 3 & 3 \\
7 & $6.2 .2 . \mathrm{d}$ & 3 & 3 & 3 \\
8 & $6.2 .2 . \mathrm{e}$ & 3 & 3 & 3 \\
9 & 6.3 & 2 & 3 & 3 \\
10 & $6.3 . \mathrm{a}$ & 2 & 2 & 2 \\
11 & $6.3 . \mathrm{b}$ & 3 & 3 & 3 \\
12 & $6.3 . \mathrm{c}$ & 3 & 2 & 3 \\
13 & 6.4 & 2 & 2 & 3 \\
\hline
\end{tabular}

Dari tabel 6 dapat dilakukan perhitungan skor penerapan ISO 9001:2008 dari masingmasing responden dan rata-rata responden sebagai berikut.

$\begin{aligned} \text { Responden } 1 & =\text { Skor R1 } \\ & =34 / 65 \times 100 \% \\ & =\text { Skor R1 } \\ & =52.30 \% \\ \text { Responden } 2 & =\text { Skor R2 } \\ & =33 / 65 \times 100 \% \\ & =\text { Skor R2 } \\ & =50.76 \% \\ \text { Responden } 3 & =\text { Skor R3 } \\ & =36 / 65 \times 100 \% \\ & =\text { Skor R3 } \\ & =55,38 \% \\ \text { Rata-rata Klausul } & 6=\mathrm{R} 1+\mathrm{R} 2+\mathrm{R} 3 / 3 \\ & =51,42+50,47+48,57 / 3 \\ & =52,81 \%\end{aligned}$

Dari hasil penghitungan tersebut diketahui bahwa skor rata-rata responden 1 sebesar 52,30 persen, responden 2 sebesar 50,76 persen dan responden 3 sebesar 55,38 persen. Secara keseluruhan rata-rata ketiga responden adalah 52,81 persen yang berarti sistem manajemen mutu pada PT. Baliyoni Saguna masuk dalam kategori sedang.

\section{d) Rekapitulasi Klausul 7}

Rekapitulasi klausul 7 dilakukan dengan menghitung skor total dan skor tersebut untuk mendapatkan persentase manajemen mutu pada klausul 7 ISO 9001:2008. Hasil data kuisioner yang disebarkan kepada responden terkait penelitian klausul 7 ISO 9001:2008 yaitu sebagai berikut. 
Tabel 7. Rekapitulasi Klausul 7

\begin{tabular}{|c|c|c|c|c|c|}
\hline $\begin{array}{l}\mathrm{N} \\
\mathrm{O}\end{array}$ & Question & R1 & R2 & R3 & R4 \\
\hline 1 & 7.1.a & 3 & 2 & 3 & 3 \\
\hline 2 & 7.1.b & 2 & 2 & 2 & 2 \\
\hline 3 & 7.1.c & 3 & 3 & 3 & 3 \\
\hline 4 & 7.1.d & 3 & 3 & 3 & 3 \\
\hline 5 & 7.2.1.a & 3 & 3 & 3 & 3 \\
\hline 6 & 7.2.1.b & 2 & 3 & 2 & 2 \\
\hline 7 & 7.2.1.c & 3 & 2 & 2 & 2 \\
\hline 8 & 7.2.1.d & 2 & 2 & 2 & 2 \\
\hline 9 & 7.2.2.a & 2 & 2 & 2 & 2 \\
\hline 10 & $7.2 .2 . \mathrm{b}$ & 3 & 2 & 3 & 2 \\
\hline 11 & 7.2.2.c & 3 & 3 & 3 & 3 \\
\hline 12 & 7.2.3.a & 3 & 2 & 2 & 3 \\
\hline 13 & 7.2.3.b & 3 & 3 & 3 & 2 \\
\hline 14 & 7.2.3.c & 2 & 3 & 3 & 2 \\
\hline 15 & 7.3.1.a & 3 & 2 & 2 & 2 \\
\hline 16 & 7.3.1.b & 2 & 2 & 2 & 2 \\
\hline 17 & 7.3.1.c & 3 & 2 & 3 & 2 \\
\hline 18 & 7.3.2.a & 3 & 3 & 3 & 3 \\
\hline 19 & 7.3.2.b & 3 & 3 & 3 & 2 \\
\hline 20 & 7.3.2.c & 3 & 2 & 3 & 2 \\
\hline 21 & 7.3.2.d & 3 & 2 & 2 & 2 \\
\hline 22 & 7.3.3.a & 2 & 2 & 2 & 2 \\
\hline 23 & 7.3.3.b & 2 & 2 & 3 & 2 \\
\hline 24 & 7.3.3.c & 3 & 3 & 3 & 2 \\
\hline 25 & 7.3.3.d & 3 & 3 & 2 & 3 \\
\hline 26 & 7.3.4.a & 3 & 2 & 3 & 3 \\
\hline 27 & 7.3.4.b & 3 & 2 & 2 & 2 \\
\hline 28 & 7.3 .5 & 3 & 3 & 3 & 3 \\
\hline 29 & 7.3 .6 & 3 & 3 & 3 & 3 \\
\hline 30 & 7.4 .1 & 2 & 2 & 2 & 2 \\
\hline 31 & 7.4.2.a & 2 & 2 & 2 & 2 \\
\hline 32 & 7.4.2.b & 2 & 2 & 2 & 2 \\
\hline 33 & 7.4.2.c & 3 & 3 & 3 & 3 \\
\hline 34 & 7.4 .3 & 3 & 2 & 3 & 3 \\
\hline 35 & 7.5.1.a & 2 & 2 & 2 & 3 \\
\hline 36 & 7.5.1.b & 2 & 2 & 2 & 2 \\
\hline 37 & 7.5.1.c & 2 & 2 & 2 & 2 \\
\hline 38 & 7.5.1.d & 2 & 3 & 2 & 2 \\
\hline 39 & 7.5.1.e & 3 & 3 & 2 & 3 \\
\hline 40 & 7.5.1.f & 3 & 2 & 2 & 3 \\
\hline 41 & 7.5.2.a & 2 & 2 & 2 & 2 \\
\hline 42 & 7.5.2.b & 2 & 3 & 3 & 3 \\
\hline 43 & 7.5.2.c & 2 & 3 & 3 & 2 \\
\hline 44 & $7.5 .2 . \mathrm{d}$ & 3 & 3 & 3 & 3 \\
\hline 45 & 7.5.2.e & 2 & 2 & 2 & 3 \\
\hline
\end{tabular}




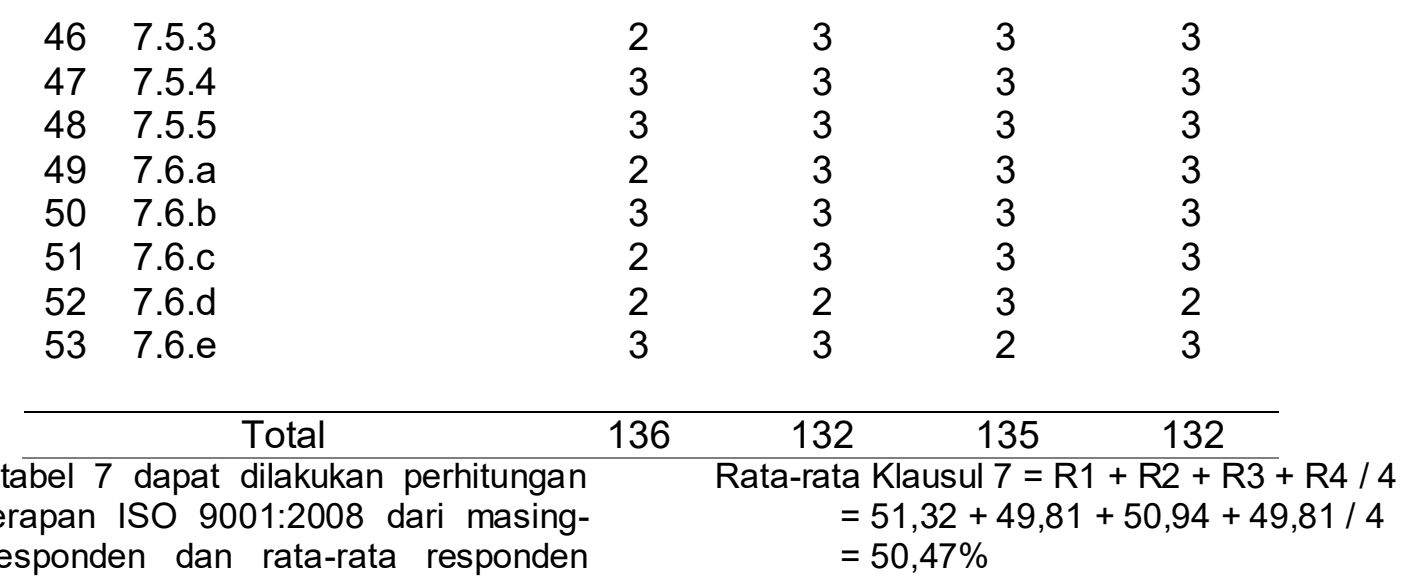

masing responden dan rata-rata responden sebagai berikut.

$$
\begin{aligned}
\text { Skor Rn } & =\text { Skor Total } / \\
100 \% & \\
\text { Responden } 1 & =\text { Skor R1 } \\
& =136 / 265 \times 100 \% \\
& =\text { Skor R1 } \\
& =51,32 \% \\
\text { Responden 2 } & =\text { Skor R2 } \\
& =132 / 265 \times 100 \% \\
& =\text { Skor R2 } \\
& =49.81 \% \\
\text { Responden 3 } & =\text { Skor R3 } \\
& =135 / 265 \times 100 \% \\
& =\text { Skor R3 } \\
& =50.94 \% \\
\text { Responden 4 } & =\text { Skor R4 } \\
& =132 / 265 \times 100 \% \\
& =\text { Skor R4 } \\
& =49,81 \%
\end{aligned}
$$

Dari hasil perhitungan tersebut didapatkan rata-rata skor penilaian responden 1 sebesar 51,32 persen, responden 2 sebesar 49,81 persen, responden 3 sebesar 50,94 persen dan responden 4 sebesar 49,81 persen sehingga keempat hasil data tersebut dapat mencari skor rata-rata. dari klausul 7 secara keseluruhan adalah 50,47 persen yang berarti sistem manajemen mutu pada PT. Baliyoni Saguna masuk dalam kategori sedang.

c) Rekapitulasi Klausul 8

Rekapitulasi klausul 8 dilakukan dengan menghitung skor total dan skor untuk mendapatkan persentase manajemen mutu pada klausul 8 ISO 9001:2008. Hasil data kuisioner yang disebarkan kepada responden terkait klausul 8 penelitian ISO 9001-2008 adalah berikut.

Tabel 8. Rekapitulasi Klausul 8

\begin{tabular}{clcccccc}
\hline No & Question & R1 & R2 & R3 & R4 & R5 & R6 \\
\hline 1 & $8.1 . \mathrm{a}$ & 2 & 3 & 2 & 3 & 2 & 3 \\
2 & $8.1 . b$ & 2 & 3 & 3 & 3 & 3 & 2 \\
3 & $8.1 . \mathrm{c}$ & 2 & 3 & 3 & 3 & 3 & 3 \\
4 & $8.2 . .1$ & 2 & 2 & 2 & 2 & 2 & 2 \\
5 & $8.2 .2 . \mathrm{a}$ & 2 & 2 & 2 & 2 & 2 & 2 \\
6 & 8.2 .3 & 2 & 3 & 3 & 2 & 3 & 3 \\
7 & 8.2 .4 & 2 & 3 & 2 & 3 & 3 & 3 \\
8 & $8.3 . \mathrm{a}$ & 2 & 3 & 2 & 2 & 2 & 2 \\
9 & $8.3 . \mathrm{b}$ & 3 & 2 & 2 & 3 & 3 & 2 \\
10 & $8.3 . \mathrm{c}$ & 3 & 2 & 2 & 3 & 3 & 3 \\
11 & $8.3 . \mathrm{d}$ & 2 & 3 & 2 & 3 & 2 & 3 \\
12 & $8.4 . \mathrm{a}$ & 3 & 2 & 3 & 2 & 2 & 2 \\
13 & $8.4 . \mathrm{b}$ & 2 & 2 & 3 & 2 & 3 & 2 \\
14 & $8.4 . \mathrm{c}$ & 2 & 2 & 3 & 3 & 2 & 2 \\
15 & $8.4 . \mathrm{d}$ & 3 & 3 & 3 & 3 & 3 & 3 \\
16 & 8.5 .1 & 3 & 2 & 2 & 2 & 2 & 2 \\
17 & $8.5 .2 . \mathrm{a}$ & 2 & 3 & 3 & 3 & 3 & 2 \\
18 & $8.5 .2 . \mathrm{b}$ & 3 & 3 & 3 & 2 & 3 & 2 \\
\hline
\end{tabular}




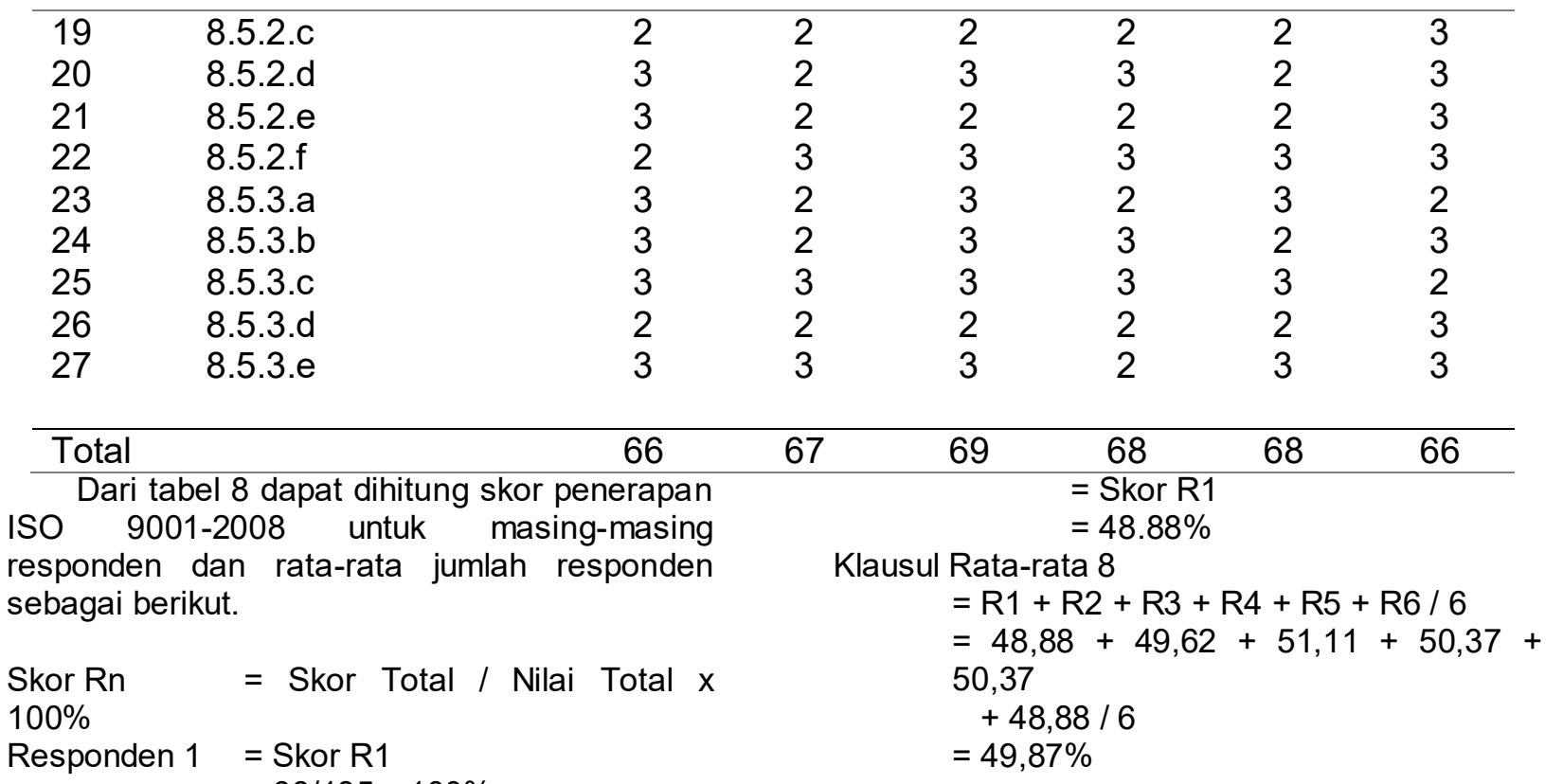

Dari hasil perhitungan tersebut didapatkan rata-rata skor penilaian responden 1 sebesar 48,88 persen, responden 2 sebesar 49,62 persen, responden 3 sebesar 51,11 persen, responden 4 sebesar 50,37 persen, responden 5 sebesar 50,37 persen, dan responden 6 sebesar 48,88 persen persen sehingga dari keempat hasil data dapat diketahui bahwa skor rata-rata klausul 8 secara keseluruhan adalah 49,87 persen yang artinya sistem manajemen mutu pada PT. Baliyoni Saguna masuk dalam kategori sedang.

\section{Analisis Rekapitulasi Total Quality Management \\ Dari rekapitulasi klausul 4, klausul 5,} klausul 6, klausul 7 dan klausul 8, dapat dibuat rekapitulasi total sebagai berikut.

Tabel 6. Rekapitulasi Total

\begin{tabular}{clcc}
\hline No & \multicolumn{1}{c}{ Clause } & Recapitulation \\
\hline 1 & Clause 4 (Quality management system) & $50,15 \%$ \\
2 & Clause 5 (Management Responsibilities) & $49,83 \%$ \\
3 & Clause 6 (Resource Management) & $52,81 \%$ \\
4 & Clause 7 (Product Realization) & $50,47 \%$ \\
5 & Clause 8 (Measurement, Analysis and Improvement) & $49,87 \%$ \\
\hline \multicolumn{2}{c}{ Average } & $50,62 \%$ \\
\hline \multicolumn{2}{c}{ Berdasarkan rekapitulasi total semua } & ISO 9001:2008 pada PT Baliyoni Saguna \\
klausul yang diuji dalam analisis manajemen & mendapatkan skor sedang atau telah \\
mutu ISO 9001:2008 di PT. Baliyoni Saguna & menerapkan manajemen mutu yang memadai. \\
mendapat skor 50,62 persen Skor tersebut &
\end{tabular}

menunjukkan manajemen mutu berdasarkan 
KESIMPULAN

Pengukuran tingkat manajemen mutu pada PT. Baliyoni Saguna telah berhasil dilakukan dengan menggunakan kuesioner yang dirumuskan berdasarkan klausul ISO 9001: 2008. Berdasarkan rekapitulasi kuesioner klausul 4 yaitu sistem manajemen mutu diperoleh skor $50,15 \%$ yang berarti bahwa sistem manajemen mutu telah diterapkan dalam skala sedang. Selanjutnya hasil klausul 5 yaitu tanggung jawab manajemen dengan skor $49,83 \%$ yang berarti tanggung jawab manajemen telah dilaksanakan dalam skala sedang. Pada hasil klausul 6 yaitu pengelolaan sumber daya diperoleh skor $52.81 \%$ yang berarti pengelolaan sumber daya telah dilaksanakan dalam skala sedang. Pada klausul 7 yaitu realisasi produk diperoleh skor $50,47 \%$ yang berarti realisasi produk telah diterapkan pada skala sedang. Pada klausul 8 yaitu pengukuran, analisis dan perbaikan diperoleh skor $49,87 \%$ yang berarti pengukuran, analisis dan perbaikan telah dilaksanakan dalam skala sedang. Berdasarkan hasil keseluruhan klausul yang telah diujicobakan, PT Baliyoni Saguna telah menerapkan manajemen mutu ISO 9001: 2008 sebesar 50,62 persen. Berdasarkan skor rata-rata tersebut maka dapat diklasifikasikan bahwa penerapan manajemen mutu pada PT. Baliyoni Saguna sudah memiliki sistem, ada bentuk, sudah diimplementasikan namun dokumentasi kurang lengkap. Berdasarkan hasil penelitian ini, perusahaan disarankan untuk meningkatkan manajemen mutu ISO 9001: 2008 sehingga menjadi lebih efektif dengan melengkapi dokumentasi perusahaan.

\section{REFERENSI}

[1] K. Budiarta, A. P. S. Iskandar, and M. Sudarma, "Audit Information System Development using COBIT 5 Framework (case Study: STMIK STIKOM Bali) Komang," Int. J. Eng. Emerg. Technol., vol. 1, no. 1, pp. 1-5, 2016.

[2] A. Goharshenasan and A. Shahin, "Prioritisation of quality management principles based on critical success factors of TQM using integrated approach of MCDM and IPA - The case of Marjan Tile Company," Int. J. Product. Qual. Manag., vol. 21, no. 1, pp. 112128, 2017, doi: 10.1504/IJPQM.2017.083285.

[3] I GUSTI AGUNG AYU ISTRI LESTARI, "Penerapan Sistem Manajemen Mutu Iso 9001:2008 Di Perusahaan Konstruksi," Ganec Swara, vol. 9, no. 1, pp. 121-126,
2015.

[4] M. L. Schrum, M. Johnson, M. Ghuy, and M. C. Gombolay, "Four years in review: Statistical practices of likert scales in human-robot interaction studies," ACM/IEEE Int. Conf. Human-Robot Interact., pp. 43-52, 2020, doi: 10.1145/3371382.3380739.

[5] M. Kebede Adem and S. S. Virdi, "The effect of TQM practices on operational performance: an empirical analysis of ISO 9001: 2008 certified manufacturing organizations in Ethiopia," TQM J., vol. 33, no. 2, pp. 407-440, 2020, doi: 10.1108/TQM-03-2019-0076.

[6] A. P. Ferreira and M. Lopes, "A case of certified units in a Portuguese university: Interactions of ISO 9000 norms with HRM practices, employee performance and employee satisfaction," Product. Organ. Manag., pp. 21-48, 2017, doi: 10.1515/9783110355796-002.

[7] F. Ramadhany and S. Supriono, "ANALISIS PENERAPAN SISTEM MANAJEMEN MUTU ISO 9001:2015 DALAM MENUNJANG PEMASARAN (Studi pada PT Tritama Bina Karya Malang)," J. Adm. Bisnis $\mathrm{S1}$ Univ. Brawijaya, vol. 53, no. 1, pp. 31-38, 2017.

[8] D. Larasati, "Implementasi Sistem Manajemen Mutu (Smm) Berbasis Iso 9001:2008 Dalam Lembaga Pendidikan (Studi Pada SMAN 5 Malang)," J. Adm. Publik Mhs. Univ. Brawijaya, vol. 1, no. 1, p. $72504,2013$.

[9] Suyitno, "The implementation of quality management system using ISO 9001:2008 based Total Quality Management Concept," J. Soc. Sci. J. Soc. Sci., vol. 77 , no. 1110 , pp. 15-27, 2018, doi: 10.25255/jss.2018.7.1.15.27.

[10] I. Suta, I. Mahendra, and M. Sudarma, "Application of COBIT 5 for Hospital Services Management Information System Audit," Int. J. Eng. dan Emerg. Technol., vol. 3, no. 2, pp. 18-23, 2018.

[11] B. Neyestani, "Effectiveness of Quality Management System (QMS) on Construction Projects," SSRN Electron. J., no. 76754, 2017, doi: 10.2139/ssrn.2960422.

[12] A. T. Prakasa, N. W. Setyanto, and L. T. W. N. Kusuma, "Analisis Penerapan Sistem Manajemen Mutu ISO 9001:2008 Menggunakan GAP Analisis Tools (Studi Kasus PT. Sahabat Rubber Industries, Malang)," J. Rekayasa dan Manaj. Sist. Ind., vol. 3, no. 1, pp. p11-21, 2015. 
[13] B. Assalam and K. Tegal, "Penerapan Sistem Manajemen Mutu Iso 9001:2008 Sebagai Upaya Peningkatan Mutu Layanan Sd It Bias Assalam Kota Tegal," J. Elem. Educ., vol. 4, no. 1, pp. 7-12, 2015.

[14] D. Astuti, "Pengaruh Implementasi Sistem Manajemen Mutu Iso 9001:2008 Terhadap Peningkatan Kualitas Layanan Di Upt Perpustakaan Politeknik Negeri Semarang," J. IImu Perpust., vol. 4, no. 3, 2015.

[15] P. Sampaio, P. Saraiva, and A. G. Rodrigues, "ISO 9001 certification research: Questions, answers and approaches," Int. J. Qual. Reliab. Manag., vol. 26, no. 1, pp. 38-58, 2009, doi: 10.1108/02656710910924161.

[16] N. Othman, S. Sanury, M. Mokhtar, M. Norhasni, and M. Asaad, "Quality Management System ISO 9001:2008 and ISO 9001:2015 Standards Within
Higher Education Institutions," J. Glob. Bus. Soc. Entrep., vol. 3, no. 6, pp. 4046, 2017.

[17] G. B. Subiksa, K. A. B. Permana, and M. Sudarma, "Audit E-Signature Public Service Project Using Knowledge Quality Management," Int. J. Eng. Emerg. ..., pp. 41-46, 2017.

[18] K. Sa'diah, "the Effect of the Quality Management System Iso 9001: 2008 and the Contribution of the Internal Audit Upon the Organizational Performance At Lp3I," Account. J. BINANIAGA, vol. 02, no. 01, pp. 1-20, 2017.

[19] A. Frederika, I. G. K. Sudipta, and H. S. Yoga, "EVALUASI PENERAPAN STANDARISASI MUTU (ISO) 9001:2008 PADA PT.MULTI SARANA PROPERTINDO (STUDI KASUS: PROYEK HOTEL GRAND WHIZ DI LEGIAN) Ariany," Tjyybjb.Ac.Cn, vol. 3, no. 2252, pp. 58-66, 2019. 